\title{
KONFLIK DAN TINDAK KEKERASAN DI ERA PASCA ORDE BARU SERTA UPAYA MENUMBUHKAN INTEGRASI NASIONAL DI INDONESIA
}

\author{
Oleh: Murtamadji \\ (FIP - UNY)
}

\begin{abstract}
Abstrak
Kajian ini bertujuan untuk mencoba mengungkap faktor penyebab timbulnya konflik dan tindak kekerasan di Indonesia, dan mencoba menganalisis langkah-langkah yang perlu diupayakan dalam rangka menumbuhkan integrasi nasional di Indonesia. Dari hasil kajian dapat disimpulkan bahwa konflik dan tindak kekerasan yang terjadi di pasca Orde Baru hingga sekarang bukanlah disebabkan oleh faktor agama, namun agama merupakan media yang sangat efektif untuk mengerahkan massa, maksudnya agama akan mudah menjadi media penggerak massa untuk melakukan tindak kekerasan dan konflik bila masyarakat mengalami ketidakberdayaan politik dan ekonomi, sebagai akibat adanya struktur politik dan ekonomi yang timpang, kekecewaan, ketidakadilan maupun ketidakpuasan terhadap pemerintah pusat yang sentralistik.

Integrasi timbul melalui proses interaksi dan komunikasi yang intensif, dalam arti kelompok kelompok yang terhimpun menjadi satu kesatuan membentuk jaringan jaringan komunikasi dengan cara-cara represif karena berhubungan dengan sosialisasi nilai-nilai sosial budaya yang menjadi konsensus bersama, pemberian perlakuan yang sama, pemberian kesempatan yang sama untuk berperan serta dalam pembangunan di segala bidang, serta adanya ikatan fungsional di antara kelompok-kelompok yang terhimpun dalam satu kesatuan. Oleh karenanya integrasi akan terbentuk dan terbina dengan baik melalui proses yang panjang.
\end{abstract}

\section{Pendahuluan}

Bermacam tindak kekerasan yang muncul dalam bentuk amuk massa, yang terjadi di tahun-tahun terakhir ini tepatnya di era pasca Orde Baru sungguh memprihatinkan, bahkan semakin mengkhawatirkan. Kekerasan massal itu ditandai dengan adanya tindak pengeroyokan, penganiayaan, pemerkosaan, pengrusakan, bahkan pembunuhan. Masjid, gereja, kantor pemerintah, dan fasilitas 
umum telah menjadi sasaran pembakaran yang dilakukan massa yang sedang kalap. Konflik dan tindak kekerasan ini tentunya dapat mengancam persatuan dan kesatuan bangsa yang selama ini kita junjung tinggi. Maka sudah sepatutnya jika berbagai pihak berupaya membuat pernyataan dan analisis dalam rangka mencari penjelas sekaligus solusi dari masalah tersebut.

Pernyataan-pernyataan yang dikeluarkan oleh berbagai pihak baik dari pejabat atau instansi resmi cenderung menegaskan bahwa berbagai tindak kekerasan tersebut diwarnai oleh unsur keagamaan, misalnya di Surabaya terjadi perampokan terhadap orang-orang yang sedang beribadah di sebuah gereja, di Dili terjadi peristiwa perusakan masjid dan gereja protestan, di Larantuka terjadi peristiwa pengeroyokan dan penganiayaan terhadap seorang Muslim oleh sekelompok pemuda Katolik, di Ujung Pandang massa Islam merusak toko-toko Cina, dan lain-lain. Total perkiraan sementara korban dan kerugian akibat kerusuhan SARA kurun 1995-1998 adalah 6 pasar, 540 kios/toko, 77 rumah tinggal, 12 fasilitas publik, 17 pabrik, 1 masjid, 32 gereja, 2 vihara, 217 mobil dan 20 orang meninggal dunia. (Heru Nugroho, 1998: 1). Selain itu, peristiwa tindak kekerasan juga dilakukan oleh kelompok GAM terhadap orang-orang yang berasal dari luar Aceh akhir-akhir ini lantaran mereka menuntut referendum dan penarikan militer keluar dari Aceh, dan peristiwa penyerangan terhadap kelompok Muslim oleh kelompok non Muslim di Ambon yang menyebabkan puluhan jiwa menjadi korban ini sungguh memprihatinkan.

Peristiwa-peristiwa konflik dan tindak kekerasan tersebut merupakan ancaman bagi persatuan dan kesatuan bangsa di masa mendatang yang perlu diwaspadai dan diantisipasi. Atas dasar itulah maka tulisan ini akan mencoba mengungkap faktor-faktor penyebab terjadinya konflik dan tindak kekerasan di Indonesia, serta mencoba untuk menganalisis mengenai upaya yang perlu ditempuh untuk menumbuhkan kohesi sosial dalam rangka integrasi nasional.

\section{Faktor Faktor Penyebab Terjadinya Konflik di Indonesia}

Peristiwa-peristiwa tindak kekerasan yang terjadi di seputar tahun 1995 hingga akhir masa kekuasaan Orde Baru yang membawa korban nyawa, harta, serta tempat peribadatan pemeluk agama, sebenarnya tidak dapat dianggap sebagai konflik keagamaan di negara kita, sebab peristiwa-peristiwa tindak kekerasan dan amuk massal itu tidak diawali dari dua kelompok yang eksklusif, misalnya antara Islam 
dan Kristen. Agama masih lebih mencerminkan ciri khas kepercayaan orang per orang pada Tuhannya dan bukan merupakan identitas yang eksklusif dari satu komunitas. Hal ini dapat diketahui bahwa di negara kita orang yang berbeda agama satu dengan yang lain tidak terpisah dalam kehidupan sehari-hari. Mereka bergaul dan berhubungan secara wajar dengan warga yang beragama lain, lantaran sudah adanya sikap toleransi antar umat beragama di Indonesia. Atas dasar itulah maka agama sebenarnya bukanlah penyebab utama dari peristiwa tindak kekerasan tersebut. Adanya pembakaran tempat ibadah (dalam hal ini gereja) dan adanya tindak kekerasan terhadap umat Islam sebenarnya hanyalah sebagai sasaran pelampiasan kemarahan rakyat terhadap kekuasaan sentralistik yang menekan masyarakat (rakyat), dan rakyat tidak berdaya untuk melawan kekuasaan negara tersebut. Akibatnya, rakyat yang marah dan tidak berdaya untuk melawan kekuasaan tersebut berusaha mencari pelampiasan kemarahan pada kelompokkelompok kecil yang mereka pastikan tidak akan mampu untuk membalasnya. Hal ini seperti yang dinyatakan oleh Galtung (dalam hasil laporan penelitian Mohtar Mas'oed, 1997: 23-24) bahwa fenomena kekerasan terutama yang terjadi pada masyarakat yang sedang aktif memantapkan kehadiran birokrasi nasional di seluruh tanah air dan menggalakan akumulasi kapital. Dalam kondisi dinamik itu, kekerasan bisa terjadi akibat tindakan yang dilakukan oleh negara, pelaku bisnis, maupun oleh komunitas, tetapi umumnya kekerasan yang dilakukan oleh komunitas sebenarnya merupakan reaksi terhadap kekerasan yang dilakukan oleh negara dan kapital, yaitu sebagai reaksi terhadap berbagai hal yang menghalangi kemungkinan manusia untuk mengaktualisasikan potensi dirinya, seperti tindak sewenang wenang oleh birokrasi dan kekerasan struktural yang berupa ketimpangan, ketidakadilan, eksploitasi, marginalisasi, kemiskinan, dan berbagai penyakit struktural lain yang muncul akibat tindakan pengendali kapital dengan dukungan negara. Contohnya adalah peristiwa di Dili Timor Timur, yakni lantaran rakyat atau masyarakat setempat tidak berdaya menghadapi masalah integrasi yang belum selesai tuntas, yang ditandai dengan adanya kelompok yang menghendaki agar Timor Timur melepaskan diri dari Negara Kesatuan Republik Indonesia, namun kelompok penentang integrasi tersebut tidak berdaya menentang kekuasaan negara. Maka kelompok tersebut melampiaskan kemarahannya kepada kelompok Muslim yang merupakan kelompok kecil (kelompok minoritas ) di wilayah itu.

Adanya tindak kekerasan, penganiayaan, dan pemerkosaan terhadap golongan etnik Cina serta pembakaran toko/kios milik Cina, 
sebenarnya disebabkan oleh adanya kecemburuan golongan pribumi terhadap keberhasilan etnik Cina dalam bidang ekonomi. Keberhasilan ekonomi etnik Cina tersebut sebagai hasil kolusi dengan beberapa oknum pejabat pemerintah jelas akan menambah kecemburuan ekonomis golongan pribumi terhadap etnik Cina. Kecemburuan antar etnik tersebut akan menimbulkan suatu gejala yang oleh Nasikun disebutnya sebagai ethnic politics, dan gejala ini akan sangat membahayakan negara Indonesia yang bersifat multi etnik. Dia selanjutnya juga memperingatkan bahwa masalah potensial yang dapat timbul dalam waktu lima sampai sepuluh tahun mendatang adalah ancaman perpecahan nasional yang berawal dari krisis ekonomi, rasialisme, dan pertentangan agama (Saafroedin Bahar, 1994: 28).

Faktor lain yang menimbulkan konflik adalah lajunya penetrasi kapital di pedesaan, sehingga masyarakat kehilangan kontrol dalam memanfaatkan sumber alam yang ada di kawasan mereka. Pemberian hak penguasaan hutan pada pengusaha besar serta perluasan perkebunan kelapa sawit di beberapa wilayah di luar Jawa berdampak pada semakin sempitnya ruang dan juga mengecilnya pendapatan dari hutan, yang sebenarnya merupakan sumber pendapatan wilayah tersebut. Selain itu berkurangnya kepercayaan (legitimasi) masyarakat terhadap birokrasi, pelayanan publik yang tidak baik, ketidakpekaan birokrasi terhadap aspirasi masyarakat akibat kebijakan pembangunan yang bersifat seragam juga menjadi penyebab timbulnya ketegangan sosial masyarakat yang sewaktu waktu akan menjadi penyebab munculnya tindakan kekerasan.

Faktor-faktor tersebut di atas yang terpendam dalam masyarakat yang hingga kini belum ada jalan pemecahannya, sehingga masyarakat (rakyat) kecewa dan mudah marah. Masyarakat juga cenderung berusaha melampiaskan kemarahan mereka kepada kelompok lain yang mereka pastikan tidak berani membalasnya, yang boleh jadi tindak kekerasan dan amuk massal terhadap kelompok lain tersebut disebabkan oleh adanya isu yang sepele dan belum pasti kebenarannya.

\section{Upaya Menumbuhkan Integrasi Nasional}

Integrasi sering dikonsepsikan atau diberi pengertian sebagai suatu proses ketika kelompok-kelompok sosial tertentu dalam masyarakat saling menjaga keseimbangan untuk mewujudkan kedekatan hubungan-hubungan sosial, ekonomi, dan politik. 
Kelompok-kelompok sosial tersebut bisa terwujud atas dasar agama atau kepercayaan, suku, ras, dan kelas (Sunyoto Usman, 1994: 79). Bertolak dari pengertian ini maka integrasi tidak harus homogen, dengan menghilangkan perbedaan-perbedaan yang ada, namun yang penting dalam konsep integrasi tersebut adalah memelihara kesadaran untuk selalu menjaga keseimbangan hubungan. Atas dasar itulah maka keberadaan dan ciri khas masing-masing kesatuan kelompok sosial yang terhimpun dalam satu kesatuan kelompok sosial yang besar (misal scope negara) tetap memperoleh pengakuan. Pengertian integrasi tersebut sebenarnya juga mengisyaratkan bahwa integrasi timbul melalui proses interaksi dan komunikasi yang intensif, dalam arti kelompok-kelompok yang terhimpun menjadi satu kesatuan membentuk jaringan-jaringan komunikasi dengan tetap mengakui adanya perbedaan-perbedaan. Kelompok-kelompok sosial yang berintegrasi membentuk jaringan hubungan dalam satu kesatuan sosial yang kohesif.

Sebelum mengemukakan upaya-upaya untuk mewujudkan integrasi nasional yang mantap di Indonesia, terlebih dahulu penulis akan melihat teori tentang bagaimana suatu masyarakat terintegrasi. Kemudian penulis baru menguraikan keadan yang nyata di dalam masyarakat kita.

Teori integrasi menyatakan bahwa suatu sistem sosial (masyarakat) terintegrasi di atas landasan kata sepakat (konsensus) para anggotanya akan nilai-nilai kemasyarakatan tertentu, suatu general agreement yang memiliki daya mengatasi perbedaanperbedaan pendapat dan kepentingan di antara anggota masyarakat. Ia memandang masyarakat sebagai suatu sistem yang secara fungsional terintegrasi ke dalam suatu bentuk equilibrium (keseimbangan).

Masyarakat senantiasa terintegrasi juga oleh karena berbagai anggota masyarakat sekaligus menjadi anggota dari berbagai kesatuan sosial (cross cutting affiliation). Oleh karena dengan demikian setiap konflik yang terjadi di antara suatu kesatuan sosial dengan kesatuankesatuan sosial yang lain segera akan dinetralisasi oleh adanya loyalitas ganda (cross cutting loyalities) dari para anggota masyarakat terhadap berbagai kesatuan sosial (Nasikun, 1993: 62). Selain itu masyarakat juga dapat terintegrasi oleh adanya kesadaran organis yang diikat oleh adanya saling ketergantungan di antara bagian-bagian dari suatu sistem sosial ( masyarakat).

Bertolak dari teori yang pertama di atas, maka Pancasila sebagai dasar falsafah negara dan pandangan hidup pada tingkat yang umum telah diterima sebagai kesepakatan nasional yang lahir bersamaan 
dengan kelahiran Negara Kesatuan Republik Indonesia. Bahkan lebih dari pada itu Pancasila pada hakikatnya dapat dipandang juga sebagai perwujudan dari nasionalisme itu sendiri, sebab Pancasila pada dasarnya merupakan pernyataan bersama dari berbagai unsur masyarakat Indonesia untuk menumbuhkan suatu sikap toleransi dan akomodasi secara timbal balik yang bersumber pada pengakuan akan kebhinnekaan masyarakat Indonesia. Ia meliputi toleransi dan akomodasi yang timbal balik dalam bidang keagamaan, kesukuan, kedaerahan, maupun pelapisan sosial. Selain itu Pancasila pada dasarnya merupakan pernyataan tekad bersama bangsa Indonesia untuk menyelenggarakan kehidupan bersama bangsa Indonesia di atas dasar Ketuhanan Yang Maha Esa, kemanusiaan yang adil dan beradab, persatuan indonesia, kerakyatan yang dipimpin oleh hikmah kebijaksanaan dalam permusyawaratan/perwakilan, dan keadilan sosial bagi seluruh rakyat Indonesia. Kemudian nilai-nilai luhur yang terkandung di dalam Pancasila tersebut dituangkan dalam bentuk norma hukum yang berupa Undang-Undang Dasar 1945. Dalam kedudukannya yang demikian itu maka Pancasila dapat dipandang sebagai scurity belt (sabuk pengaman persatuan), atau dengan kata lain Pancasila dapat dipandang sebagai faktor yang mengintegrasikan masyarakat Indonesia.

Meskipun demikian hal itu bukan berarti telah selesai. Salah satu persoalan yang sangat penting di masa yang akan datang sebenarnya adalah terletak pada sosialisasi (pembudayaan) Pancasila itu sendiri. Sosialisasi (pembudayaan) Pancasila, sebagaimana sosialisasi nilai-nilai yang lazim dijadikan pedoman yang membimbing hidup bermasyarakat, berbangsa, dan bernegara hendaknya diusahakan agar berjalan melalui mekanisme sedemikian rupa agar dalam masyarakat tidak hanya berkembang pemikiran yang tekstual dan yang berorientasi pada aspek kognitif (terbatas pada aspek ilmu pengetahuan) saja, namun yang lebih penting daripada itu seharusnya juga diupayakan agar berkembang pemikiran-pemikiran yang berorientasi pada aspek afektif atau yang mengarah pada pembentukan sikap, perilaku, dan tindakan nyata yang merupakan cerminan nilai-nilai Pancasila sebagai dasar falsafah negara dan pandangan hidup, sehingga Pancasila telah benar-benar dilaksanakan secara kontekstual dalam kehidupan bermasyarakat, berbangsa, dan bernegara, yang pada gilirannya akan menumbuhkan kesadaran dan keyakinan bahwa di dalam Pancasila terkandung nilai-nilai yang mempunyai kekuatan untuk mempersatukan bangsa. 
Mengacu kepada teori yang kedua dapat diketahui bahwa di dalam masyarakat yang majemuk yang terdiri dari bermacam macam golongan atau kelompok tidak jarang terjadi bahwa seorang individu tertentu dalam waktu yang sama menjadi anggota dua atau lebih kelompok sosial yang berbeda. Dari gejala keanggotaan ganda ini akan timbul gejala lain dalam masyarakat yang disebut kesetiaan ganda. Kondisi semacam itu hendaknya justru kita dukung dengan menghilangkan sikap sukuisme, primordialisme, maupun fanatisme kelompok, dan sebaliknya justru perlu kita kembangkan sikap keterbukaan, sedia bekerja sama dengan kelompok lain dan sikap toleransi dan saling hormat-menghormati antara sesama pemeluk agama dan lain sebagainya. Umpamanya dalam proses kegiatan sosial, ekonomi, dan politik hendaknya diadakan pembagian peran yang sama dan objektif, yaitu didasarkan pada kemampuan maupun keahlian serta prestasi masing-masing dan bukan atas dasar prestise, kesamaan golongan, kesamaan suku, kesamaan keturunan, karena koneksi, dan lain-lain, sebab yang demikian itu memungkinkan setiap orang akan memperoleh peluang yang sama dalam meraih status sosial ekonomi yang diingini, dengan melalui kerja keras dan memacu prestasi dan tidak akan berusaha mencari hubungan/koneksi kepada orang-orang yang mempunyai posisi jabatan yang tinggi. Dengan demikian, akan terjadi suatu persaingan yang sehat dan kesetiaan pada kelompok mantap atau tidak semu. Namun sebaliknya jika pembagian peran itu berdasarkan koneksi karena adanya kesamaan suku, golongan, agama, keturunan, daerah asal dan sebagainya justru akan menjadi penyebab semakin kuatnya ikatan primordialisme dan mendorong anggota masyarakat untuk selalu berusaha mencari koneksi kepada orang-orang yang mempunyai posisi jabatan tinggi. Dalam kondisi seperti ini maka persaingan untuk memperoleh status sosial ekonomi yang tinggi menjadi tidak sehat, dan justru akan menumbuhkan loyalitas (kesetiaan) yang semu, karena kesetiaan itu munculnya disebabkan oleh adanya kepentingan yang berupa pamrih, dan jika kepentingan tadi berubah maka sikapnya pun akan berubah pula, yaitu kesetiaannya akan berubah pula.

Selain itu perlu adanya demokratisasi dalam struktur kekuasaan organisasi-organisasi kemasyarakatan. Artinya, dalam proses pengambilan keputusan yang penting hendaknya melibatkan seluruh komponen organisasi yang ada dan bukan hanya diputuskan oleh sekelompok elit minoritas yang berkuasa. Dengan melibatkan seluruh komponen organisasi kemasyrakatan yang ada dalam mengambil keputusan yang penting akan dapat dicegah tumbuhnya kesetiaan pada 
kelompok minoritas yang berkuasa, bahkan akan dapat tumbuh partisipasi politik warga negara yang ada di daerah-daerah yang pada gilirannya juga akan menumbuhkan rasa kebersamaan.

Di bagian muka dari tulisan ini telah dikemukakan bahwa masyarakat dapat pula terintegrasi oleh adanya kesadaran organis yang diikat oleh adanya saling ketergantungan di antara bagian-bagian dari suatu sistem sosial. Maka ada tiga hal yang perlu diperhatikan dalam upaya menumbuhkan integrasi nasional. Pertama, dalam menyusun kebijaksanaan pembangunan ekonomi, misalnya, diupayakan agar tidak hanya mengejar pertumbuhan ekonomi yang tinggi saja, namun juga hendaknya diupayakan agar ada pemerataan pendapatan di daerah-daerah. Karena pembangunan ekonomi yang hanya mengejar pertumbuhan akan menyebabkan mereka yang dekat dengan orang-orang yang berkuasa akan lebih mudah untuk melakukan kolusi dengan penguasa dalam rangka usahanya untuk dapat memonopoli aset-aset pembangunan. Hal ini jika tidak dikendalikan akan membuat mereka semakin melejit atau meningkat sangat cepat yang pada gilirannya akan dapat mengeksploitasi kelompok-kelompok kecil. Dengan demikian, tidak memungkinkan terjadinya suatu bentuk hubungan kerja sama antara kelompok kecil yang lemah dengan kelompok besar yang kuat lantaran hubungan yang terjadi antara kelompok kecil dengan kelompok yang besar tadi sudah bersifat istimewa dan monopolistik. Padahal hubungan saling ketergantungan itu akan tumbuh jika terjadi hubungan kerja sama yang saling menguntungkan. Atas dasar itulah maka hanya dengan melaksanakan kebijaksanaan pembangunan yang merata dan pemberian otonomi daerah yang lebih luas memungkinkan berkurangnya hubungan-hubungan yang bersifat istimewa dan monopolistik antara pemerintah pusat dengan pemerintah daerah, dan sebaliknya hal itu justru akan menumbuhkan hubungan kerja sama yang saling menguntungkan di antara kelompok-kelompok tersebut. Adanya kerja sama yang saling menguntungkan tersebut dapat menjadi pengikat persatuan di antara mereka.

Kedua, bahwa kebijaksanaan pembangunan (terutama ekonomi) harus memperhatikan keterkaitan antara berbagai macam sektor, sektor formal dan nonformal, sektor agraris tradisional dengan industrial modern, serta sektor perekonomian desa dengan sektor perekonomian kota. Hanya inilah yang memungkinkan terkikisnya bentuk-bentuk hubungan yang sifatnya superordinasi dan subordinasi antar sektor, maupun berkurangnya kecemburuan sosial ekonomi antar kelompok (sektor), lantaran perkembangan sektor-sektor tersebut 
dapat terkendali oleh pemerintah melalui kebijaksanaankebijaksanaannya. Berkurangnya kecemburuan sosial ekonomi antar kelompok berarti juga akan memungkinkan berkurangnya bahkan hilangnya prasangka mengenai ketidakadilan pemerintah dalam hal pembuatan kebijaksanaan pembangunan ekonomi yang justru pada gilirannya akan meningkatkan kepercayaan masyarakat pada pemerintah.

Ketiga, lembaga-lembaga birokrasi hendaknya dapat dipacu sedemikian rupa sehingga dapat memberikan pelayanan yang baik kepada semua lapisan masyarakat terutama pada kelompok lapisan masyarakat yang paling bawah, karena dengan demikian akan dapat memberdayakan dan mendorong partisipasi masyarakat lapisan bawah di dalam proses pembangunan politik dan ekonomi, sehingga dapat tercegah terjadinya penguasaan proses pembuatan keputusan yang penting oleh kelompok lapisan atas saja. Keputusan-keputusan yang dibuat tersebut biasanya cenderung menguntungkan kelompok lapisan atas dan mengorbankan kelompok lain yang lebih lemah yang pada gilirannya justru akan berakibat pada kelompok lapisan bawah yang lemah tersebut, yakni semakin tersingkir dan semakin miskin sebagai akibat adanya struktur politik, ekonomi, dan sosial yang timpang tersebut.

R. William Liddle (dalam Nasikun, 1970: 205) berpendapat bahwa terwujudnya integrasi nasional yang tangguh menuntut dipenuhinya suatu syarat mutlak yang berupa suatu penyelenggaraan kehidupan di semua bidang, bagi seluruh lapisan dan golongan masyarakat, yang betul-betul sesuai dengan nilai-nilai dasar yang telah disepakati bersama. Bertolak dari pendapat ini, maka pada akhirnya yang menentukan berhasil tidaknya integrasi nasional di Indonesia dan terselenggaranya kehidupan masyarakat pada semua aspek kehidupan nasional, telah benar-benar mencerminkan nilai-nilai luhur yang telah diyakini kebenarannya dan yang disepakati bersama, yaitu Pancasila, terutama sila keadilan sosial bagi seluruh rakyat Indonesia yang merupakan bagian integral dari Pancasila. Jika kehidupan bermasyarakat dan bernegara itu diselenggarakan dengan berkeadilan, toleransi, setia kawan, kerukunan, kerja sama, pengendalian diri dan ada kesanggupan serta kemauan untuk menjalin komunikasi dua arah dengan membuka diri untuk berdialog antar golongan baru dimungkinkan prasangka negatif ketidakadilan itu berkurang.

Syarat tersebut benar-benar merupakan tantangan yang berat baik di masa sekarang maupun di masa yang akan datang. Oleh karena itu, yang terpenting bagi semua warga negara Indonesia adalah 
mengusahakan agar dari kondisi kemajemukan masyarakat Indonesia tersebut justru dapat mendorong timbulnya gairah, aktivitas, dan dinamika untuk menuju ke masyarakat yang bersatu. Kiranya takada jalan lain untuk menjawab dan menghadapi tantangan tadi kecuali dengan merencanakan dan melaksanakan pembangunan di semua bidang secara adil dan merata.

\section{Kesimpulan}

Dari seluruh uraian di atas dapat disimpulkan bahwa agama sebenarnya bukanlah penyebab utama terjadinya konflik dan tindak kekerasan yang terjadi di seputar tahun 1995 hingga saat ini. Agama memang merupakan media yang sangat efektif untuk menggerakan massa, tetapi keefektifan agama sebagai penyebab konflik dan tindak kekerasan sangat tergantung dari kondisi yang disandang masyarakat. Agama akan mudah menjadi media penggerak massa untuk melakukan tindak kekerasan dan konflik jika masyarakat mengalami ketidakberdayaan politik dan ekonomi sebagai akibat adanya struktur politik dan ekonomi yang timpang .

Pengertian integrasi sebenarnya tidak harus homogen dan harus menghilangkan perbedaan-perbedaan yang ada, namun yang penting dalam konsep integrasi tersebut adalah adanya kesadaran untuk selalu menjaga keseimbangan hubungan. Atas dasar itulah maka keberadaan dan identitas (ciri khas) masing-masing kesatuan kelompok sosial yang terhimpun dalam satu kesatuan kelompok sosial yang besar (negara) tetap diakui.

Integrasi timbul melalui proses interaksi dan komunikasi yang intensif, dalam arti kelompok-kelompok yang terhimpun menjadi satu kesatuan membentuk jaringan-jaringan komunikasi dengan tetap mengakui adanya perbedaan-perbedaan. Maka integrasi tidak dapat diciptakan dengan cara-cara represif, karena berhubungan dengan sosialisasi nilai-nilai, pemberian perlakuan dan kesempatan yang sama untuk berperan, dan adanya ikatan fungsional di antara kelompokkelompok yang terhimpun dalam satu kesatuan. Oleh karena itu, integrasi terbentuk melalui proses yang panjang.

\section{Daftar Pustaka}

Heru Nugroho. 1997. "Agama dan Pembinaan Ketahanan Nasional". Makalah dalam Seminar Nasional Di Pasca Sarjana UGM Yogyakarta, pada tanggal 30 Nopember 1997. 
Mohtar Mas'oed. 1997. “Tantangan Terhadap Integrasi Bangsa (Studi Kasus Konflik Sosial dan Kerusuhan Masal)". Laporan Penelitian, yang dilakukan oleh P3PK UGM Bekerja sama dengan Depag RI.

Nasikun. 1993. Sistem Sosial Indonesia, Jakarta: PT Raja Grafindo Persada.

Sunyoto Usman. 1994. "Integrasi Nasional dan Ketahanan Nasiona"l. Dalam Kumpulan Makalah Seminar Nasional yang disunting Ichlasul Amal \& Armaidy Armawi. Yogyakarta: Gadjah Mada University Press.

Saafroedin Bahar. 1994. "Masalah Ethnisitas dan Ketahanan Nasional: Resiko Atau Potensi". Makalah Seminar Nasional, Prodi Tan Nas Pasca Sarjana UGM Yogyakarta, pada tanggal 1 Desember 1994.

R. William Liddle. 1970. Ethnicity, Party and National Integration: An Indonesian Case Study, New Haven and London: Yale University Press.

\section{Biodata Penulis}

Murtamadji, lahir di Yogyakarta, 8 Februari 1954, lulus Fisipol Sosiologi UGM 1983, dan lulus Magister (S-2) Ketahanan Nasional di UGM Yogyakarta pada tahun 2001. Mulai bekerja di IKIP Yogyakarta (UNY sekarang) tahun 1986 di Jurusan MKU FPIPS. Sekarang menjadi dosen di FSP FIP UNY. 